\title{
Peningkatan Keterampilan Berbicara Melalui Metode Bermain Peran Pada Siswa Kelas II SDN Karangrejo 04 Jember
}

\author{
Nadila Yuniati, Suhartiningsih, Zetti Finali \\ Jurusan Ilmu Pendidikan, Fakultas Keguruan dan Ilmu Pendidikan, Universitas Jember (UNEJ) \\ Jln.Besuki, Bondowoso 68251 \\ E-mail: suhartiningsih.fkip@unej.ac.id
}

\begin{abstract}
Abstrak
Penelitian ini dilatarbelakangi oleh adanya permasalahan yang terjadi dalam keterampilan berbicara yang terbukti dengan dilakukan tanya jawab pada saat pembelajaran oleh guru hanya beberapa siswa yang dapat menjawab, dikarenakan banyak siswa yang masih malu dan kurang percaya diri dalam mengungkapkan pendapatnya. Menurut data awal tersebut, ada beberapa penyebab rendahnya keterampilan berbicara siswa, seperti kurangnya ketertarikan siswa saat pembelajaran Bahasa Indonesia serta kurangnya materi yang diberikan. Penelitian ini bertujuan untuk mengetahui bagaimanakah proses penerapan metode bermain peran dan bagaimanakah peningkatan keterampilan berbicara siswa melalui metode bermain peran pada siswa kelas II di SDN Karangrejo 04 Jember?. Rancangan penelitian yang digunakan dalam penelitian ini adalah rancangan penelitian tindakan kelas. Subjek penelitian ini adalah siswa-siswi kelas II SDN Karangrejo 04 Jember pada semester ganjil tahun 2019/2020 dengan jumlah siswa 34 siswa yang terdiri 20 siswa laki-laki dan 14 siswa perempuan. Metode pengumpulan data yang digunakan yaitu melalui metode wawancara dan metode dokumentasi. Analisis data yang digunakan yaitu analisis kualitatif dan kuantitatif dengan cara memberikan skor pada setiap indikator keterampilan berbicara yang dinilai. Hasil analisis menunjukkan rendahnya keterampilan berbicara siswa kelas II. Berdasarkan hasil analisis tersebut, dapat disimpulkan bahwa rendahnya keterampilan berbicara siswa kelas II di SDN Karangrejo 04 Jember. Faktor-faktor yang menyebabkan kesalahan tersebut adalah ketidak tertarikan siswa siswa dan kurangnya pemberian materi kepada siswa.
\end{abstract}

Kata Kunci: keterampilan berbicara dan bermain peran.

\section{Abstract}

This research is motivated by the problems that occur in speaking skills as evidenced by the question and answer while learning by the teacher only a few students can answer, because many students are still shy and lack of confidence in expressing their opinions. According to the preliminary data, there are several reasons for the lack of students' speaking skills, such as the lack of student interest in learning Indonesian and the lack of material provided. This study aims to find out how the process of applying the role playing method and how to improve students' speaking skills through the role playing method in class II students at SDN Karangrejo 04 Jember? The research design used in this study was a classroom action research design. The subjects of this study were students of class II SDN Karangrejo 04 Jember in the odd semester of 2019/2020 with a total of 34 students consisting of 20 male students and 14 female students. Data collection methods used are through the interview method, the documentation method. Analysis of the data used is qualitative and quantitative analysis by giving a score on each indicator of the assessed speaking skills. The results of the analysis showed the low speaking skills of class II students. Based on the results of the analysis, it can be concluded that the low speaking skills of second grade students at SDN Karangrejo 04 Jember. The factors that cause these errors are the students' lack of interest and the lack of giving material to students.

Keywords: speaking and role playing skills.

\section{Pendahuluan}

Bahasa memiliki peranan penting dalam perkembangan intelektual, sosial, dan emosional peserta didik. Bahasa Indonesia merupakan salah satu mata pelajaran yang harus diajarkan pada semua jenjang pendidikan termasuk di sekolah dasar. Pembelajaran bahasa Indonesia terdiri atas empat keterampilan berbahasa meliputi keterampilan mendengarkan, berbicara, membaca, dan menulis. Keterampilan yang dibutuhkan peserta didik yakni keterampilan berbicara. Keterampilan berbicara sangat penting untuk mempermudah berkomunikasi dengan orang lain.
Menurut Satria (2008) mengatakan bahwa keterampilan adalah kegiatan yang memerlukan praktik atau dapat diartikan sebagai implikasi dari aktivitas [1]. Sedangkan Musaba mengemukakan bahwa berbicara berarti berkomunikasi secara lisan. Oleh sebab itu, banyak hal yang harus diperhatikan, misalnya berkaitan dengan penggunaan bahasa, penampilan fisik, keadaan mental, dan situasi sosial budaya yang melingkupi proses pembicaraan atau komunikasi itu sendiri [2].

Menurut Sanjaya mengatakan bahwa bermain peran adalah metode pembelajaran sebagai bagian dari simulasi yang diarahkan untuk mengkreasi peristiwa sejarah, mengkreasi peristiwa-peristiwa aktual, atau kejadian- 
kejadian yang mungkin muncul pada masa mendatang [3]. Implementasi keterampilan berbicara bidang studi Bahasa Indonesia kelas II yang tercakup dalam kurikulum 2013 dengan kompetensi dasar 3.1 Merinci ungkapan, ajakan, perintah, penolakan yang terdapat dalam teks cerita atau lagu yang menggambarkan sikap hidup rukun dan kompetensi dasar 4.1 Menirukan Merinci ungkapan, ajakan, perintah, penolakan yang terdapat dalam teks cerita atau lagu anakanak dengan bahasa yang santun Berdasarkan hasil observasi yang dilakukan pada 30 Juli 2019, diketahui bahwa keterampilan berbicara siswa kelas II SDN Karangrejo 04 Jember masih rendah. Terbukti dengan dilakukannya tanya jawab pada saat pembelajaran guru memberikan pertanyaan akan tetapi hanya sedikit siswa yang mampu mengutarakan pendapat mereka dengan baik, kebanyakan siswa masih malu dan kurang percaya diri dalam mengungkapkan pendapatnya. Suasana kelas juga kurang kondusif karena beberapa siswa sering mengganggu saat temannya mengutarakan pendapat. Selain itu siswa kesulitan dalam berbicara seperti merangkai kata dalam berbicara kurang tertata juga menjadi kendala siswa dalam berpendapat, kosa kata yang sering digunakan siswa saat pembelajaran juga masih tercampur dengan bahasa ibu atau bahasa daerah. Berdasarkan latar belakang permasalahan di atas, maka rumusan masalah dalam penelitian ini adalah, (1) bagaimanakah proses penerapan metode bermain peran pada siswa kelas II SDN Karangrejo 04 Jember, (2) bagaimanakah peningkatan keterampilan berbicara siswa melalui penerapan metode bermain peran pada siswa kelas II SDN Karangrejo 04 Jember?. Penelitian ini bertujuan, (1) untuk mendeskripsikan penerapan metode bermain peran untuk meningkatkan keterampilan berbicara siswa kelas II SDN Karangrejo 04 Jember, (2) untuk meningkatkan keterampilan berbicara siswa melalui penerapan metode bermain peran pada siswa kelas II SDN Karangrejo 04 Jember

\section{Metode Penelitian}

Jenis penelitian yang digunakan dalam penelitian ini adalah penelitian tindakan kelas (PTK). Penelitian Tindakan Kelas atau PTK secara umum dapat diartikan sebagai suatu penelitian tindakan kelas yang diterapkan dalam kegiatan belajar mengajar di kelas. Jadi dapat disimpulkan bahwa PTK merupakan suatu langkah tindakan untuk memperbaiki kualitas, baik proses maupun hasil pembelajaran di kelas yang dilaksanakan oleh guru dengan menggunakan Penelitian Tindakan Kelas diharapkan dapat meningkatkan keterampilan berbicara siswa kelas II di SDN Karangrejo 04 Jember.

Subjek penelitian ini adalah siswa kelas II SDN Karangrejo 04 Jember tahun pelajaran 2019/2020. Adapun jumlah subjek penelitian adalah 34 siswa yang terdiri atas 20 siswa laki-laki dan 14 siswa perempuan. Data yang dikumpulkan dalam penelitian ini berupa (1) hasil observasi yang dilakukan observer selama kegiatan pembelajaran dengan menerapkan media cerita bergambar, (2) hasil wawancara guru dan siswa sebelum dan setelah kegiatan pembelajaran dengan menerapkan metode bermain peran, (3) hasil tes tulis dengan menerapkan metode bermain peran, dan (4) dokumen berisi data nama siswa kelas II SDN
Karangrejo 04 Jember. Sumber data yang digunakan dalam penelitian ini adalah guru dan seluruh siswa kelas II SDN Karangrejo 04 Jember berjumlah 34 siswa yang terdiri atas 20 siswa laki-laki dan 14 siswa perempuan pada tahun 2019/2020.

Analisis data kuantitatif dalam penelitian ini meliputi analisis keterampilan berbicara siswa. Analisis data kuantitatif dilakukan untuk mengetahui peningkatan keterampilan berbicara siswa sebelum dan sesudah penerapan metode bermain peran dalam pembelajaran keterampilan berbicara. Penilaian terhadap keterampilan berbicara siswa kelas II SDN Karangrejo 04 Jember, dilakukan dengan memberikan skor pada setiap indikator keterampilan berbicara yang dinilai. Adapun kriteria penilaian keterampilan berbicara dengan menggunakan skor akan dijelaskan seperti dibawah ini.

Tabel 1. Kriteria Pedoman Penilaian Keterampilan Berbicara

\begin{tabular}{|c|c|c|c|}
\hline & Keterangan & Skor & $\begin{array}{c}\text { Kriteria } \\
\text { Penilaian }\end{array}$ \\
\hline & $\begin{array}{l}\text { Membaca dengan mengucapkan } \\
\text { bunyi bahasa secara tepat dan jelas }\end{array}$ & 25 & $\begin{array}{l}\text { Sangat } \\
\text { Baik }\end{array}$ \\
\hline & $\begin{array}{l}\text { Membaca dengan mengucapkan } \\
\text { bunyi bahasa dengan jelas namun } \\
\text { terdapat pengaruh ucapan daerah }\end{array}$ & 20 & Baik \\
\hline & $\begin{array}{l}\text { Membaca dengan mengucapkan } \\
\text { bunyi bahasa secara samar-samar } \\
\text { dan kurang jelas }\end{array}$ & 15 & Cukup \\
\hline & $\begin{array}{l}\text { Membaca dengan mengucapkan } \\
\text { bunyi tidak jelas dan ucapan sulit } \\
\text { dimengerti }\end{array}$ & 10 & Kurang \\
\hline & $\begin{array}{l}\text { Membaca dengan tinggi rendahnya } \\
\text { nada dan keras lembutnya tekanan } \\
\text { secara jelas }\end{array}$ & 15 & $\begin{array}{l}\text { Sangat } \\
\text { Baik }\end{array}$ \\
\hline & $\begin{array}{l}\text { Membaca dengan tinggi rendahnya } \\
\text { nada secara jelas namun keras } \\
\text { lembutnya tekanan pada saat } \\
\text { membaca kurang jelas }\end{array}$ & 10 & Baik \\
\hline & $\begin{array}{l}\text { Membaca dengan tinggi rendahnya } \\
\text { nada tidak terlalu jelas dan keras } \\
\text { lembutnya tekanan pada saat } \\
\text { membaca kurang }\end{array}$ & 8 & Cukup \\
\hline & $\begin{array}{l}\text { Tidak dapat membaca dengan } \\
\text { tinggi rendahnya nada dan keras } \\
\text { lembutnya tekanan }\end{array}$ & 5 & Kurang \\
\hline \multirow{4}{*}{$\begin{array}{l}\text { Pemilih } \\
\text { an Kata }\end{array}$} & $\begin{array}{l}\text { Pemilihan kata saat berdialog tepat } \\
\text { dan sesuai }\end{array}$ & 15 & $\begin{array}{l}\text { Sangat } \\
\text { Baik }\end{array}$ \\
\hline & $\begin{array}{l}\text { Pemilihan kata saat berdialog tepat } \\
\text { dan efektif. }\end{array}$ & 10 & Baik \\
\hline & $\begin{array}{l}\text { Pemilihan kata saat berdialog } \\
\text { kurang tepat dan kurang efektif. }\end{array}$ & 8 & Cukup \\
\hline & $\begin{array}{l}\text { Pemilihan kata saat berdialog tidak } \\
\text { tepat dan tidak efektif. }\end{array}$ & 5 & Kurang \\
\hline \multirow{3}{*}{$\begin{array}{l}\text { Penguas } \\
\text { aan } \\
\text { topik }\end{array}$} & $\begin{array}{l}\text { Penguasaan topik pada saat } \\
\text { berdialog runtut dan jelas. }\end{array}$ & 15 & $\begin{array}{l}\text { Sangat } \\
\text { Baik }\end{array}$ \\
\hline & $\begin{array}{l}\text { Penguasaan topik pada saat } \\
\text { berdialog runtut. }\end{array}$ & 10 & Baik \\
\hline & Penguasaan topik pada saat & 8 & Cukup \\
\hline
\end{tabular}




\begin{tabular}{|l|l|l|l|}
\hline & $\begin{array}{l}\text { berdialog tidak runtut dan } \\
\text { diingatkan teman. }\end{array}$ & & \\
\hline $\begin{array}{l}\text { Penguasaan topik pada saat } \\
\text { berdialog tidak runtut dan tidak } \\
\text { jelas. }\end{array}$ & 5 & Kurang \\
\hline Mimik & $\begin{array}{l}\text { Raut muka dan gerak tubuh dalam } \\
\text { memperjelas maksud dialog, } \\
\text { terutama yang berkaitan dengan } \\
\text { unsur emosinya sangat baik. }\end{array}$ & 20 & $\begin{array}{l}\text { Sangat } \\
\text { Baik }\end{array}$ \\
\hline $\begin{array}{l}\text { Raut muka baik dan gerak tubuh } \\
\text { kurang dalam memperjelas maksud } \\
\text { dialog, terutama yang berkaitan } \\
\text { dengan unsur emosinya. }\end{array}$ & 15 & Baik \\
\hline $\begin{array}{l}\text { Raut muka kurang dan gerak tubuh } \\
\text { baik dalam memperjelas maksud } \\
\text { dialog, terutama yang berkaitan } \\
\text { dengan unsur emosinya. }\end{array}$ & 10 & Cukup \\
\hline $\begin{array}{l}\text { Raut muka dan gerak tubuh dalam } \\
\text { memperjelas maksud dialog, } \\
\text { terutama yang berkaitan dengan } \\
\text { unsur emosinya sangat kurang }\end{array}$ & 5 & Kurang \\
\hline
\end{tabular}

Sumber: Arsjad dan Mukti [4] ajakan, perintah, penolakan yang terdapat dalam teks cerita atau lagu anak-anak dengan bahasa yang santun.

c. Pengamatan

Pengamatan dilakukan bersamaan dengan proses pembelajaran berlangsung. Pengamatan dilakukan untuk mengamati aktivitas siswa dalam kegiatan pembelajaran di kelas dan Pengamatan yang dilakukan terhadap guru untuk menggambarkan proses pembelajaran melalui penerapan metode bermain peran. Gambaran kegiatan guru dan siswa diamati oleh pengamatan, yaitu guru kelas dan mahasiswa.

d. Refleksi

Pada tahap kegiatan refleksi dilakukan setelah kegiatan pembelajaran dan observasi di kelas. Beberapa permasalahan yang ditemukan pada pembelajaran siklus I, yaitu:

1) Beberapa siswa masih belum mampu berbicara dengan pemilihan kata dengan tepat. Saat bermain peran di depan kelas, bahasa yang digunakan tidak baku;

2) Beberapa siswa masih belum mampu menguasai topik dengan baik, sering lupa dengan dialog akibatnya siswa yang lain yang membantu.

3) Sebagian besar siswa mampu menggunakan intonasi dengan baik meskipun terkadang jedanya tidak sesuai.

Tabel 2. Kriteria Hasil Belajar Siswa $\quad$ 4) Sebagian besar siswa sudah mampu memainkan

\begin{tabular}{|l|l|c|}
\hline No & \multicolumn{1}{|c|}{ Kualifikasi } & Rentangan Skor \\
\hline 1 & Sangat Baik & $80-100$ \\
\hline 2 & Baik & $70-80$ \\
\hline
\end{tabular}

mimik wajah dengan baik, tetapi beberapa orang masih malu mengekspresikan emosinya.

5) Pengucapan lafal sebagian siswa sudah baik, beberapa siswa pengucapan dialaog daerah masih ada.

\begin{tabular}{|l|l}
\hline 3 & Cukup Baik \\
\hline 4 & Kurang Baik \\
\hline 5 & Sangat Kurang Baik \\
\hline
\end{tabular}
$70-80$ $60-70$ $40-60$

2. Siklus II

a. Perencanaan Beberapa perencanaan yang dilaksanakan pada penelitian ini yaitu.

1) Menyusun silabus dan rencana pelaksanaan pembelajaran (RPP) pembelajaran Bahasa Indonesia pembelajaran keterampilan berbicara menggunakan metode bermain peran.

\section{Hasil dan Pembahasan}

2) Menyusun bahan pembelajaran.

Penerapan Metode Pembelajaran Bermain Peran yang Dapat Meningkatkan Keterampilan Berbicara Siswa Kelas II SDN Karangrejo 04 Jember

\section{Siklus 1}

3) Menyusun lembar kerja siswa (LKS) beserta kunci jawabannya.

\section{a. Perencanaan}

1) Menyusun silabus dan rencana pelaksanaan pembelajaran (RPP) pembelajaran Bahasa Indonesia pembelajaran keterampilan berbicara menggunakan metode bermain peran.

2) Menyusun bahan pembelajaran.

3) Menyusun lembar kerja siswa (LKS) beserta kunci jawabannya.

4) Menyusun pedoman observasi kegiatan guru dan siswa selama proses pembelajaran.

\section{b. Pelaksanaan Tindakan}

Pelaksanaan siklus I dilaksanakan 2 kali pertemuan yaitu pada hari Rabu, 14 Agustus 2019 dan Kamis, 15 Agustus 2019 dengan alokasi waktu mulai dari pukul 09.3010.30. Kompetensi dasar pada siklus I yaitu 3.1 Merinci ungkapan, ajakan, perintah, penolakan yang terdapat dalam teks cerita atau lagu yang menggambarkan sikap hidup rukun dan kompetensi dasar 4.1 Menirukan Merinci ungkapan,
4) Menyusun pedoman observasi kegiatan guru dan siswa selama proses pembelajaran.

b. Pelaksanaan

Pelaksanaan siklus II dilaksanakan 2 kali pertemuan yaitu pada hari Senin, 19 Agustus 2019 dan Selasa, 20 Agustus 2019 dengan alokasi waktu mulai dari pukul 09.3010.30. Kompetensi dasar pada siklus I yaitu 3.1 Merinci ungkapan, ajakan, perintah, penolakan yang terdapat dalam teks cerita atau lagu yang menggambarkan sikap hidup rukun dan kompetensi dasar 4.1 Menirukan Merinci ungkapan, ajakan, perintah, penolakan yang terdapat dalam teks cerita atau lagu anak-anak dengan bahasa yang santun.

c. Pengamatan

Pengamatan dilakukan bersamaan dengan proses pembelajaran berlangsung. Pengamatan dilakukan untuk mengamati aktivitas siswa dalam kegiatan pembelajaran di kelas dan pengamatan yang dilakukan terhadap guru untuk menggambarkan proses pembelajaran melalui penerapan metode bermain peran. Gambaran kegiatan guru dan siswa diamati oleh observer, yaitu guru kelas dan mahasiswa.

d. Refleksi 
Refleksi pada siklus II dilakukan untuk melihat hasil dari penelitian yang telah dilakukan pada siklus II. Semua masalah yang terjadi pada siklus I sudah dibenahi dalam siklus II. Adapun hasil refleksi pada siklus II yaitu.

1) Setelah guru menjelaskan ulang dan menyuruh siswa mencari kesalahan pada naskah teks, siswa dapat melakukan pemilihan kata dengan tepat;

2) Setelah guru menyuruh siswa untuk menghafalkan naskah terlebih dahulu sesuai dengan peran masingmasing siswa dapat bermain peran dengan lancar.

3) Setelah guru memberikan penjelasan dan contoh penggunaan intonasi yang tepat, siswa dapat menggunakan intonasi dengan tepat;

4) Setelah guru memberikan motivasi, siswa tidak malu untuk berekspresi.

5) Setelah guru melakukan penjelasan dan pelatihan siswa dapat menggunakan Bahasa Indonesia yang tepat.

B. Peningkatan Keterampilan Berbicara Setelah Diterapkan Metode Bermain Peran pada Siswa Kelas II SDN Karangrejo 04 Jember

1. Keterampilan Berbicara Siklus I

Dari hasil presentase diperoleh data bahwa bahwa terdapat 15 siswa dari 34 siswa atau sebesar $42,43 \%$ yang tergolong kriteria sangat baik, 11 siswa dari 34 siswa atau sebesar 33,33\% tergolong kriteria baik, 7 siswa tergolong cukup dengan presentase $21,21 \%$, dan juga 1 siswa atau sebesar 3,03\% yang tergolong kurang dapat dilihat dari rerata klasikal pada prasiklus 64,91. Pada siklus 1 meningkat menjadi 77 dengan kriteria baik. Berdasarkan kriteria ketuntasan minimal (KKM) yang ditentukan siswa dinyatakan bahwa siswa bisa tuntas apabila memperoleh nilai $\geq 75$. Dari hasil silkus 1 diperoleh 25 siswa atau sebesar $75,75 \%$ dari 33 siswa mendapat $\geq 75$. Sedangkan 8 siswa atau sebesar $24,24 \%$ dari 33 siswa mendapat $\leq 75$. Hal ini menunjukan bahwa pada siklus 1 sudah mengalami peningkatan keterampilan berbicara, namun untuk pemantapan keterampilan berbicara perlu dilakukan perbaikan pada siklus II guna mengatasi kelemahankelemahan pada siklus I.

2. Keterampilan Berbicara Siklus II

Dari hasil presentase diperoleh data bahwa bahwa terdapat 23 siswa dari 34 siswa atau sebesar $66,66 \%$ yang tergolong kriteria sangat baik. 8 siswa dari 33 siswa atau sebesar 24,24\% tergolong kriteria baik sedangkan 3 siswa tergolong cukup atau sebesar 9,10\%. Dapat dilihat dari rerata klasikal pada siklus 1 adalah 77 dengan kriteria baik, sedangkan pada siklus II menjadi 83,42 dengan kriteria sangat baik. Hal ini menunjukan bahwa pembelajaran berhasil meningkat siswa telah mencapai KKM.

\begin{tabular}{|l|c|c|c|c|}
\hline \multicolumn{1}{|c|}{ Indikator } & Kriteria & $\begin{array}{c}\text { Rentangan } \\
\text { Skor }\end{array}$ & $\begin{array}{c}\text { Jumlah } \\
\text { Siswa }\end{array}$ & Prosentase \\
\hline Lafal & SB & $80-100$ & 23 & $66.66 \%$ \\
\hline Intonasi & $\mathrm{B}$ & $70-80$ & 8 & $24.24 \%$ \\
\hline Pemilihan Kata & $\mathrm{C}$ & $60-70$ & 3 & $9.10 \%$ \\
\hline $\begin{array}{l}\text { Penguasaan } \\
\text { Topik }\end{array}$ & $\mathrm{K}$ & $40-59$ & 0 & $0.00 \%$ \\
\hline Mimik & SK & $0-40$ & 0 & $0.00 \%$ \\
\hline
\end{tabular}

Jumlah

34

100

\section{Peningkatan Keterampilan Berbicara}

Pada siklus I setelah diterapkan metode bermain peran jumlah siswa yang memperoleh nilai $\geq 75$ sebanyak 26 siswa atau $75,76 \%$ dinyatakan tuntas. Pada siklus II setelah diterapkan metode bermain peran jumlah siswa yang mengalami peningkatan memperoleh nilai $\geq 75$ sebanyak 31 siswa atau 96,97\%. Berdasarkan pernyataan tersebut pembelajaran dinyatakan keterampilan berbicara siswa mengalami peningkatan.

\section{Kesimpulan dan Saran}

Berdasarkan hasil dan pembahasan yang telah dijelaskan maka dapat disimpulkan sebagi berikut.

1. Proses peningkatan keterampilan berbicara setelah menggunakan metode bermain peran siswa kelas II SDN Karangrejo 04 Jember semester I tahun pelajaran 2019/2020, yaitu: Memberikan penjelasan pada siswa agar dapat melakukan pemilihan kata dengan tepat dan efektif, sebelum tampil bermain peran guru menyuruh siswa untuk menghafalkan lagi dialog yang terdapat pada naskah bermain peran, guru membantu siswa untuk berbicara dengan intonasi yang baik tidak perlu berteriak cukup dapat didengar siswa yang belakang, guru memberikan motivasi kepada siswa agar percaya diri dan tidak malu untuk bermain peran, guru membantu siswa yang masih menggunakan bahasa ibu atau daerah pada saat pembelajaran dilatih menggunakan bahasa dengan benar.

2. Peningkatan keterampilan berbicara pada siswa kelas II SDN Karangrejo 04 Jember, setelah diterapkannya metode bermain peran nilai hasil keterampilan berbicara siswa yaitu. pada tahap prasiklus $(64,91)$ dengan kategori cukup, siklus I (77) kategori baik dan siklus II $(83,42)$ kategori sangat baik. Rata-rata nilai yang didapat siswa dilihat dari presentase keterampilan berbicara secara klasikal pada prasiklus 13 siswa $(36,36 \%)$ siswa yang memiliki nilai diatas KKM, pada siklus 1 sekitar 26 siswa $(75,76 \%)$ siswa yang memiliki nilai diatas KKM, lalu pada siklus 2 sekitar 31 siswa $(96,97 \%)$ siswa yang memiliki nilai diatas KKM. Kesimpulan dari penelitian ini adalah penerapan metode bermain peran dapat meningkatkan keterampilan berbicara pada siswa kelas II SDN Karangrejo 04 Jember.

Berdasarkan hasil penelitian peningkatan keterampilan berbicara melalui metode bermain peran pada siswa kelas II SDN Karangrejo 04 Jember, maka diberikan saran sebagai berikut.

1) bagi siswa, diharapkan setelah diterapkan metode bermain peran dalam pembelajaran keterampilan berbicara dengan lafal, intonasi, dan mimik yang tepat dapat berbicara dengan baik dengan lebih memperhatikan pemilihan kata yang tepat dan juga penggunaan bahasa indonesia yang tepat.

2) bagi sekolah dan guru, metode bermain peran dapat digunakan untuk melatih siswa dalam berbicara. 
Penerapan metode bermain peran dapat menjadi salah satu alternatif dalam kegiatan pembelajaran di kelas dalam rangka meningkatkan mutu pendidikan sekolah.

3) bagi peneliti lain, penelitian ini hendaknya dapat menjadi masukan atau acuan metode untuk melaksanakan penelitian sejenis dan dapat digunakan untuk menambah wawasan dalam meningkatkan keterampilan berbicara.

\section{Daftar Pustaka}

[1] Satria. 2008. Pengertian Keterampilan dan Jenisnya. Yogjakarta. Gadjah Mada University Press

[2] Musaba, Z. 2012. Terampil Berbicara. Yogyakarta: CV. Aswaja Pressindo.

[3] Sanjaya, Y. 2012. Keterampilan Berbahasa. Bandung. PT Sarana Tutorial Nuraini Sejahtera.

[4] Arsjad \& Mukti. 2008. Pembinaan Kemampuan Berbicara Bahasa Indonesia. Jakarta: Erlangga.

[5] Masyhud, S. 2016. Metode Penelitian Pendidikan. Jember: Lembaga Pengembangan.

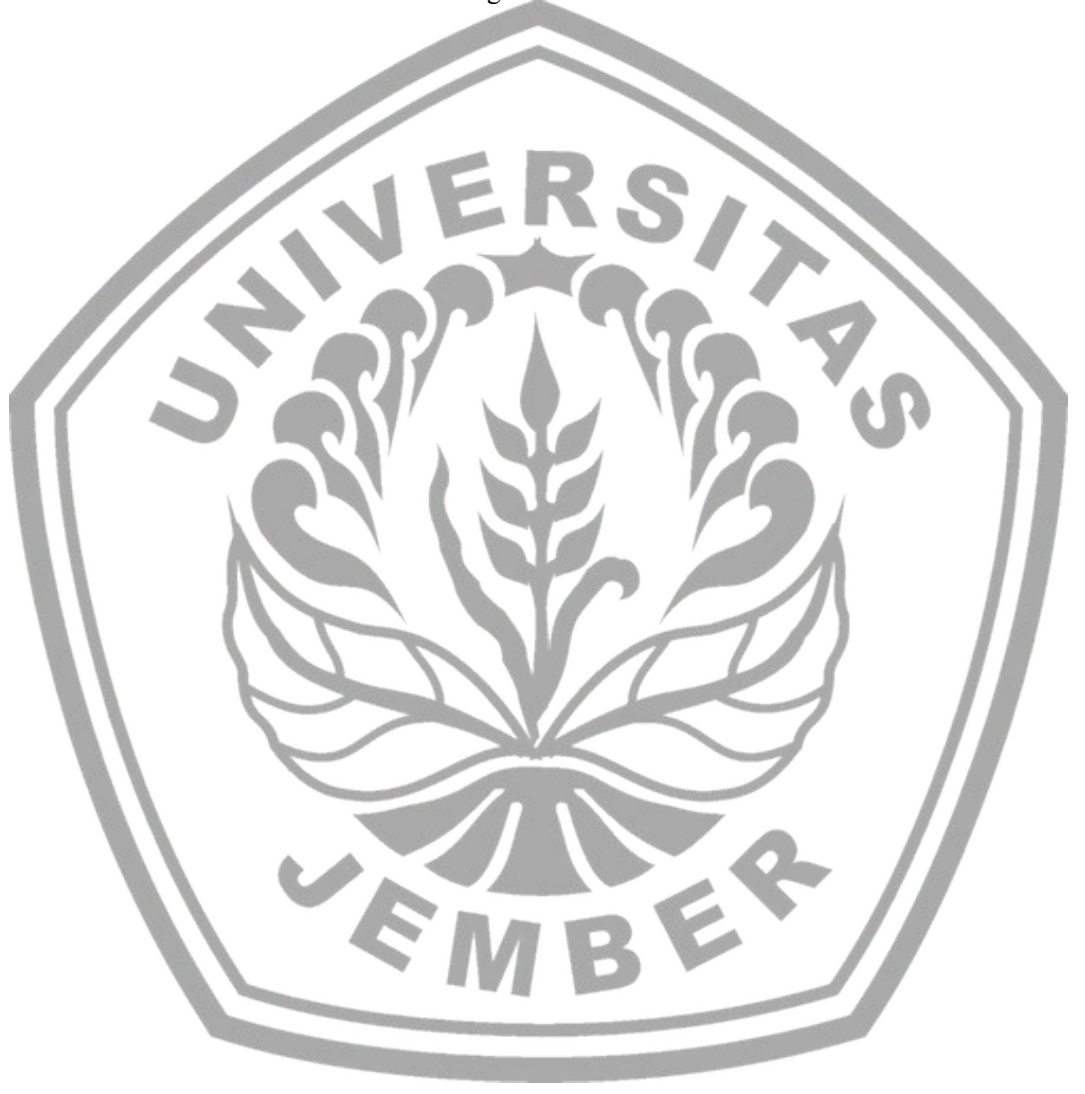

